\title{
A study of supply chain integration in the aeronautics sector
}

\author{
Rafaela Alfalla-Luque ${ }^{\mathrm{a}}$, Carmen Medina-Lopez ${ }^{\mathrm{a}}$ and Heribert Schrage \\ ${ }^{a}$ GIDEAO Research Group, University of Seville, Spain; ${ }^{b}$ Aernnova Aerospace do Brasil, Brazil
}

Corresponding author: Rafaela Alfalla-Luque

University of Seville - GIDEAO Research Group

Faculty of Economics and Business Management

Department of Financial Economics and Operations Management

Avda. Ramón y Cajal, 1. 41005. Seville. Spain

Tel.: $0034954556456 \quad$ Fax: 0034954557570

E-mail: alfalla@us.es

Carmen Medina-Lopez

University of Seville - GIDEAO Research Group

Faculty of Economics and Business Management

Department of Financial Economics and Operations Management

Avda. Ramón y Cajal, 1. 41005. Seville. Spain

Tel.: 0034954556456

Fax: 0034954557570

E-mail: cmedina@us.es

Heribert Schrage

Aernnova Aerospace do Brasil

Av. Sebastiao H. C. Pontes, 4810

12237-823 São José dos Campos - SP - Brazil

Tel.: 00551239328200

Email: heribert.schrage@aernnova.com 


\title{
A study of supply chain integration in the aeronautics sector
}

\begin{abstract}
Competitive pressure, high development costs, long lead times, rapidly changing technologies and the risks inherent in projects combined with the delays seen in the latest aircraft models (with the rise in costs that these have entailed) highlight the need to reorganise the supply chain in the aeronautics sector paying special attention to an improvement in inter- and intra-organisational integration. The aim of the present study is to analyse the situation of supply chain integration (SCI) in the aeronautics sector using three dimensions (information integration, coordination and resource sharing and organisational relationship linkage), considering both internal integration and external integration with customers and suppliers. A group of first tier supplier experts analyse the dimensions and assess the degree to which the factors that define SCI have been achieved. The results enable strengths and weaknesses to be determined and indicate possible improvements to the situation that is detected with clear managerial implications.
\end{abstract}

Keywords: Supply chain integration, aerospace, information integration, coordination, organisational relationship, focus group.

\section{Introduction}

Companies have realised that internal improvement alone is not enough for them to be competitive (Arana-Solares et al., 2011). They try to survive in the increasing complexity of the real world: highly globalised markets, rapid developments in the new information technologies, increasingly shorter product life cycles and more demanding customers. This context has changed inter-company relationships, requiring improvements to the supply chain (SC) as a whole rather than to individual companies (Ketchen and Hult, 2007; Hernández et al., 2008). Firms must set their objectives and determine their strategies depending on the SC through which they add value both to the product and the service that they are offering the customer (Mikkola and Skjøtt-Larsen, 2004; Alfalla-Luque and Medina-Lopez, 2010). These companies are inter-dependent since the individual performance of any one member affects all the others and the efficiency of the entire SC (Cigolini and Rossi, 2008). Managing the SC therefore now becomes a vital element for survival and business growth, even though research on the subject did not begin until the mid 1990s (Alfalla-Luque and Medina-Lopez, 2009).

Many papers state the need for a close and integrated relationship between SC partners (Flynn et al., 2010). Researchers generally agree that a higher level of supply chain integration (SCI) positively influences the performance of the focal organisation and its supply network 
(Frohlich and Westbrook, 2001; Vickery et al., 2003; Bagchi et al., 2005a; Moyano Fuentes, 2010). This suggests that companies should invest in strategies that promote integration across the members of the SC (Zhang et al., 2010).

The aeronautics sector is no different to any other in this respect. For about two decades, competitive pressure in aeronautics industry markets has been permanently on the increase, although sales markets have shown a strong trend growth (Ecorys, 2009; Rose-Anderssen et al., 2009). Severe competition, high development costs (Esposito and Passaro, 2009), long lead times (O’Neill and Sackett, 1994), rapidly changing technologies (Reed and Walsh, 2002), and the risks inherent in projects (Zsidisin and Smith, 2005), combined with the delays seen in the latest models of aircraft and the rise in costs that these have entailed (Ecorys, 2009) are all leading to a need for the SC in the aeronautics sector to be reorganised (Bales et al., 2004; Smith and Tranfield, 2005). This new SC is marked by vertical disintegration (Ecorys, 2009) and the search for risks being shared between partners (Rose-Anderssen et al., 2008).

In this context, the aeronautics SC is gaining in complexity (Laframboise and Reyes, 2007). Research studies are needed to improve the management of the new relationship established between the partners. One of the biggest challenges facing the industry therefore is improved integration, both internally and with suppliers and customers (Bales et al., 2004) in a quest for, inter alia, lower costs, improved productivity and quality, greater speed and flexibility, reduced inventories and faster and more reliable deliveries (Smith and Tranfield, 2005; Ecorys, 2009). Given this challenge, this research develops a study on the aerospace sector focusing on the SCI of the aeronautics industry.

The aim of this paper is to analyse internal and external integration in the aeronautics sector focusing on the first tier supplier perspective and the relationships between first tier suppliers and their main partners downstream -the Original Equipment Manufacturers (OEMs)and upstream -the second tier suppliers. Using a focus group of first tier supplier experts, the 
main variables that define SCI are studied in order to establish the current state of SCI in the aeronautics sector and to determine strengths and weaknesses and any actions that can be taken for improvement.

The remainder of this paper is organised as follows. Firstly, previous papers on SCI are reviewed. This is followed by an explanation of the research methodology developed. Next, the results are discussed. Finally, conclusions are presented.

\section{Literature review and research objectives}

\subsection{Dimensions of SCI}

SCI could be defined as the degree to which SC members achieve collaborative interand intra-organisational management on the strategic, tactical and operational levels of activities (and their corresponding physical and information flows) that, starting with raw materials suppliers, add value to the product to satisfy the needs of the final customer at the lowest cost and the greatest speed (Bagchi et al., 2005a; Cagliano et al., 2006; Flynn et al, 2010). As the definition suggests, both internal and external integration with suppliers and customers has to be considered. Several papers analyse SCI using this triple scope (Swink et al, 2007; Wong and Boon-itt, 2008; Kim, 2009). Yet, despite the importance that internal integration has for achieving inter-organisational integration (Rosenzweig et al., 2003), some papers focus only on external integration. On some occasions they focus on integration with suppliers and customers (Frohlich and Westbrook, 2001; Vachon and Klassen, 2007; Quesada et al., 2008; Sezen, 2008), but on others they focus only on integration with suppliers (Cagliano et al., 2006; Cousins and Menguc, 2006; Koufteros et al., 2007).

This is not where the complexity of the concept ends, however. Lee (2000) proposes three dimensions to define SCI and Bagchi et al. (2005b) determine five. As Table 1 shows, there is a direct relationship between them. The dimensions presented by Lee (2000) will therefore be taken into consideration when analysing SCI in the aeronautics sector and these will 
Alfalla-Luque, R., Medina-Lopez, C. \& Dey, P.K. (2013), "Supply chain integration framework using literature review". Production Planning and Control, V. 24, N. 8-9, 800-817. http://dx.doi.org/10.1080/09537287.2012.666870

be analysed from both the inter- and the intra-organisational angles from the perspective of first tier suppliers.

\section{[INSERT TABLE 1 HERE]}

\subsection{SCI in the aeronautics sector}

A complex nature characterises the SC in the aeronautics industry, which has traditionally been dominated by aircraft manufacturers, the OEMs (Bales et al., 2004). OEMs like Airbus and Boeing possess the technological capacity in design and manufacturing, as well as sufficient financial capacity, to implement the programmes that the market demands, acting as project leaders and being legally responsible for the aircraft (Esposito and Passaro, 2009). Since the development of the Boeing 787 and the A380, the SC in the sector has undergone a structural change that is forcing the OEMs to become systems integrators (Rose-Anderssen et al., 2009), manufacturing few parts of the aircraft internally compared to the traditional model of intense verticalisation (Morton et al., 2006). Boeing has pioneered this process of transforming a leading manufacturing company into a systems integrator, coordinating strategic marketing, design and assembly functions instead of producing parts and components. Airbus is following the trend started by Boeing (Ecorys, 2009).

The aeronautics SC is also seeing its numbers of direct suppliers to OEMs being reduced (AeroStrategy Management Consulting, 2007). No answers to financial needs and improved costs and lead times could be found in traditional supplier relationships. The OEMs identified a potential opportunity to gain a competitive advantage through closer integration with key suppliers (Rose-Anderssen et al., 2008). It is therefore becoming necessary to forge alliances with first tier suppliers (Risk and Revenue Sharing Partnerships) that are able to assume part of a project's industrial and financial risk, and these are included right from the product development stage (Bozdogan et al., 1998). The model might even cover not only the research and development costs but also the cost of test flights and certification. First tier suppliers have 
even demanded that their own sub-system, parts and components suppliers should shoulder greater financial and technological responsibilities. OEMs have transferred risk down the SC (Bales et al., 2004; Ecorys, 2009).

But the SC flow does not finish when the aircraft is delivered. Aftermarket support represents revenue and profit opportunities that frequently exceed revenue derived from the initial product sale (Farris et al., 2005). The outlook for the air transport MRO (Maintenance, Repair and Overhaul) market is dominated by the accelerating development of comprehensive and complicated global aftermarket service networks comprising seemingly infinite combinations of airlines, OEMs and third-party repair organisations. MRO organisations have developed broad levels of integration that include complete MRO services, asset management, and engineering support. Given its importance and complexity, MRO is considered as a subsector of its own in the aerospace industry.

Within this SC environment there is a need to work towards an improvement of the SCI (Bales et al., 2004; Ecorys, 2009). The aeronautics industry must work towards this goal as there is an evident lack of SCI compared to other sectors, such as the automotive sector. Studies have been done focusing on an analysis of SCI in specific sectors, such as industrial equipment (Sahin and Robinson, 2005), the construction industry (Briscoe and Dainty, 2005), the automotive industry (Wong and Boon-itt, 2008) and the manufacture of fabricated metal products, machinery and equipment (Frohlich and Westbrook, 2001). Multisector studies are the norm (Swink et al., 2007; Quesada et al., 2008; Sezen, 2008; Kim 2009), although the aeronautics sector is not included.

Although much has been written about the SC in general, far less has been written specifically about the aeronautics SC and its integration (Rose-Anderssen et al., 2009). No articles have been found in the previous literature that have analysed SCI as their core objective. Some aspects related to the SCI dimensions established by Lee (2000) have been sought in 
studies that analyse the aeronautics SC in general terms or the implementation of specific practices that affect the SC (Table 2). However, none focus on a detailed analysis of any particular aspect of SCI in this industry, seeking an overall vision and a step forward in this respect. The lack of studies is manifest despite the improvement of internal and external integration being one of the main challenges in the sector (Bales et al., 2004). Unlike previous studies, this paper puts the accent on an exclusive analysis of SCI using three dimensions (information integration, coordination and resource sharing and organisational relationship linkage) while considering both internal and external integration with customers and suppliers.

\section{[INSERT TABLE 2 HERE]}

\section{Methodology}

An analysis of SCI in the aeronautics sector has been conducted by consulting experts by means of individual interviews and a focus group. Interviews with experts have been extensively used in the literature with regard to this industry, and numerous case studies have been done (Russell and Hoag, 2004; Zsidisin and Smith, 2005; Laframboise and Reyes, 2007; Esposito and Passaro, 2009). The focus group is one of the most widely used research tools in social sciences, and previous studies were found in the literature that use these in the area that concerns this study, Operations Management in general (Dey et al., 2006; Binder and Edwards, 2010), and SCM in particular (Oehmen et al., 2010; Tate et al., 2010). A focus group should involve a group of six to twelve participants in a structured discussion about a particular topic (Barbour and Kitzinger, 1999; Tate et al., 2010). It is particularly useful for exploratory research like that presented in this study. The stages set out by Stewart and Shamdasani (1990) were used to conduct the focus group.

Experts from top first tier supplier plants (that have preferred to remain anonymous) in the sector that are shared risk partners with companies like Airbus and Embraer have been involved in the study. This means that they are linked to companies that are representative of 
this level (first tier suppliers) in the SC. These experts have a great deal of experience as they have been at their present company or others in the sector for at least ten years and have held management positions in Operations Management, Logistics or SCM.

The methodology that was developed begins with a round of interviews with the experts with a view to informing them of the objectives of the research, discussing the current design of the SC in the aeronautics sector in a semi-structured individual interview and providing them with the questions that were to be analysed in the focus group. These questions focused on an analysis of the dimensions set out by Lee (2000) from an intra- and inter-organisational scope. The items that determine each of the dimensions had been used in earlier studies (Frohlich and Westbrook, 2001; Stank et al., 2001; Narasimhan and Kim, 2002; Vickery et al., 2003; Bagchi et al., 2005a and 2005b; Briscoe and Dainty, 2005; Gimenez and Ventura, 2005; Sahin and Robinson, 2005; Sanders and Premus, 2005; Cagliano et al., 2006; Swink et al, 2007; Quesada et al., 2008; Sezen, 2008; Wong and Boon-itt, 2008; Kim, 2009), which gives them theoretical validity (O'Leary-Kelly and Vokurka, 1998). The second column in Table 3 presents the items considered in the study.

In the focus group the experts were asked to analyse SCI in the sector. To facilite this task, they were asked to score each of the items for both internal integration and integration with customers (OEM) and suppliers (second tier suppliers). To be specific, they had to agree on a group score on a scale from 1 (no integration) to 5 (maximum integration). The dimensions and variables were accompanied by a brief description to aid with their understanding.

The focus group was moderated by one of the authors. It began with a review of the objectives of the project and a brief presentation on the SC in the aeronautics sector, situating the first tier suppliers in the chain as a whole. Each of the factors and the scores awarded from the three perspectives under analysis were then discussed. During this stage it was underlined that participants should not make comments and score solely from the point-of-view of the 
companies in which they were executives, but by adopting an overall view that would consider the first tier supplier firms as a whole. The quantitative results that were obtained in this discussion are set out in the last three columns of Table 3.

A qualitative analysis was done of the comments that the experts made about the factors when justifying the scores that they agreed on for them. The preliminary results were commented on individually by the experts to fine tune and complete the comments that had been noted. Additional sources of evidence were also obtained from the articles on the SC in the aeronautics sector that were reviewed. Multiple data sources, including interviews, focus groups and a literature review, therefore enable triangulation in the data analysis and provide stronger substantiation of the results obtained (Eisenhardt, 1989). The data was gathered in 2009.

\section{Results}

A qualitative analysis of the three dimensions that define SCI has been done in the aeronautics sector based on the comments made by the experts. These comments support the scores given by first tier supplier experts to SCI variables (Table 3).

\section{[INSERT TABLE 3 HERE]}

\subsection{Information integration}

In this dimension, external integration has the lowest scores for collaborative planning and joint demand and replenishment forecasts as the experts state that the information flows from the OEMs more with a view to informing than really having the goal of achieving agreements on planning and forecasts. The traditional functional/departmental focus found in the sector has still not broken down intra- and inter-organisational barriers and impacts on both internal and external integration.

An analysis of the information sharing and information technology integration factors shows that experts state that the OEMs have given priority to connectivity and information 
sharing with their customers over their suppliers. They provide after-sales service to their customers through web portals where they share information and technical data for aircraft operations and MRO activities. The web portals increase the visibility needed for costs to be brought down and increased service in the manufacturing and MRO activities (Farris et al., 2005). The OEMs have looked for solutions that enable information to flow rapidly, securely and accurately with their main suppliers through web portals. The aim of these portals is to control materials, financial and information flows between the OEMs and their first tier suppliers. However, second tier suppliers and beyond will receive this information once it has been screened by first tier suppliers who have set up their own portals to communicate with their suppliers. This will cause a delay and will, on many occasions, trigger a loss of quality in the information and the bullwhip effect.

Although web portals enable individual customer-supplier communication, they do not seek any relationships between the suppliers themselves with the aim of integration and improvements. To this end, companies are developing platforms such as Exostar. The aim is to create a trusted workspace for secure information sharing, collaboration and process integration across the SC in which members work together more efficiently and with lower risk. This system is capable of connecting SC members to allow an exchange of purchase orders, provide information on delivery slips in transit, manage returns and provide materials visibility. The system also shows events and exceptions to the delivery programme, synchronising all the SC members affected by any variation in demand. Exostar enables technical documents, norms, specifications and designs to be shared, as well as the management of offer processes, which must be presented via the platform. Finally, it can also help with interfacing between the ERP systems of the companies involved in the processes (Zuckerman, 2007). Platforms like Exostar are therefore a clear step forward in integration processes. 
In other respects, ERP systems and communications systems like EDI facilitate internal processes and enable information to be shared both internally and externally. First tier suppliers also use ERPs intensively. However, less and less use is made of ERPs the further upstream you go, where small and medium size companies cannot easily access these tools for reasons of cost or training, and use specific software applications for the different functional areas that do not integrate with each other. For this reason, initiatives are being developed with the aim of facilitating the use of IT tools to sector suppliers at a lower cost through access to basic web enabled ERP modules. SAP-ECMA is a pre-configured solution, for example, that combines the different logistics flows and production processes associated with subcontractors in the aeronautics industry. Apart from covering specific requirements, the processes model included in this software is based on best practices in the sector. In other respects, ERP systems need to be improved; they often do not reflect the extra complexity of MRO activities since material flows in two directions (reverse logistics). This entails the repair order process needing to be managed manually or the ERP application modified, with the consequent increases in time and likelihood of making mistakes (MacDonnell and Clegg, 2007).

The visual management system that Airbus and Boeing have on their assembly lines must be highlighted as far as internal integration on an operational level is concerned. Production-related information regarding quality, plant engineering and logistics is fed in realtime through a computer network and projected on huge screens with a view to keeping the line balanced and running uninterruptedly. This allows the organisation to react immediately should there be any problems or stoppages. The first tier suppliers and, especially, upstream companies are still not on the same level of innovation, however. Nevertheless, there are initiatives aimed at a wider use of visual management with the goal of reducing wastage and improving process productivity (Parry and Turner, 2006). Visual management has become an important method for 
managing internal processes for second tier suppliers and upstream, as many of these companies do not have an ERP able to assist in the day-to-day running of their plant.

In general terms, the level of integration is lower for collaborative planning and joint demand and replenishment forecast factors than for information sharing and information technology integration. To a great extent this is due to the fact that OEMs use their market intelligence departments and other sources of information to analyse the markets and unilaterally lay down production plans for at least a two year period. The aircraft sales process also has a significant effect on these factors. This process follows a system of contracts with firm orders and optional orders (non-confirmed purchase quantities). When a customer formalises a firm order for aircraft there is usually an upfront payment of part of the value of the contract over the firm amount. Customers therefore delay for as long as they can before confirming their orders. Nevertheless, given the long lead times optional orders must be considered in planning, which includes aircraft that have not been allocated to any specific customers (dubbed "white tails"). This way, an attempt is made to keep a continuous flow going on the production line throughout the whole chain and to make the planning as flat as possible (with few fluctuations) so that better use is made of resources.

Integration information is also favoured by inter-company and inter-department contacts. The OEMs set times for periodic meetings with their first tier suppliers. These programmed meetings do not usually exist between first and second tier suppliers, however.

\subsection{Coordination and resource sharing}

This dimension has evident strengths in the common use of logistical equipment, agreements on delivery frequency and packaging customisation and standardisation. However, aspects such as shared decision-making and work realignment with suppliers and customers present lower levels of integration.

The shared decision-making factor is influenced by the OEMs' need to maintain total 
and direct control over materials, the production process and the way the SC is configured. The reason for this is that they are legally responsible for the final product during its useful life and they must know the traceability of all the assembled components. Materials specifications and even the definition of the production process depend on the OEM's acceptance. In this regard, companies upstream of the OEMs have not traditionally had any management capacity that might guarantee the legal control measures required for aircraft manufacturers. Moreover, OEMs did not delegate the authority for selecting raw material suppliers to them alleging their lack of technical capacity. On top of this, second tier and upstream suppliers especially do not usually possess the financial capacity to put up funds for the purchase of raw materials. Meanwhile, the few manufacturers certified to sell raw materials to the aeronautics industry that exist have often come up with obstacles for selling to small companies. This situation has resulted in there being major obstacles to suppliers regarding raw material management and has justified tight control by the OEMs.

As a result, the OEMs have dominated the SC, assigning jobs to their suppliers, and defining the way that the work is balanced according to their vision. It should be borne in mind that there is only a limited number of qualified suppliers in the sector. From the technical pointof-view, a great deal of prudence must be shown before any changes are made to the supply source as perfect interfacing with all other components has to be verified yet again. For the OEMs, the redistribution of the work load among its suppliers is a complex issue that entails high costs (certification, testing, engineering, etc.). Nevertheless, internal work realignment is a habitual practice as companies move their work load from plant to plant depending on availability and their own interests.

The complexity of the SC has led the aeronautics industry to follow a strategy of selecting and reducing the number of suppliers which is allowing work loads to be concentrated in bigger companies, with greater financial capacity and more technical and technological 
resources. And so the SC profile is changing from one of outsourcers who have no mastery over their processes to one of first tier suppliers with solid resources for managing their raw materials and their production processes. Notwithstanding, the supplier base is still configured according to the traditional model in old, stable programmes.

The needs experienced by the sector mean that companies are open to cooperation. Aeronautical suppliers traditionally group together in associations or clusters to tackle technical and management difficulties. This practice enables training costs to be reduced and companies also have stronger representation in the various forums. The clusters usually work well and on some occasions even lead to virtual companies being created. However, suppliers, especially the smaller among them, usually demand higher levels of cooperation because of their limited management structures and technical capacities.

The sector's logistics take on special importance. There is a common interest in improving customisation and standardisation of packaging for reasons of cost, safety and productivity. The process is complex due to the high number of part-numbers and the small amounts manufactured in each lot. MRO logistics is similarly complex due to the need for a rapid response to the final customer (e.g. airlines) and to reverse logistics movements that might be produced. This need for an immediate response is especially important in unplanned maintenance operations, such as in the so-called "Aircraft on Ground" (AOG) situations, which indicate that a problem is serious enough to prevent an aircraft from flying. In these cases, when replacement parts are not available, the supplier must build and deliver the parts urgently.

Supplier plants frequently set up around OEMs with the intention of gaining a competitive edge from being near the customer. Proximity is a particularly important advantage for suppliers of aeronautical structures as they are large size products and the savings in packaging, transport and handling can be significant. In this line, the OEMs use logistics platforms to support their operations and reduce costs. Logistics operators have therefore been 
found who provide third-party logistics (3PL) services by transporting, storing and distributing merchandise directly to the assembly line. But there are also the service providers that serve OEMs and first tier suppliers. Apart from the tasks carried out by the 3PL, these latter also add value to the service by handling the merchandise, and cutting the materials and distributing them to the subcontractors. This allows SC members to individually concentrate on the areas where they can provide the most value for customers (Farris et al., 2005).

Delivery frequency is overseen by the OEMs and first tier suppliers. "Milk run" systems are usually used for the suppliers who are nearest the factories and looking for transport cost reductions. These systematics take advantage of transport synergy, but can also be regarded as the starting-point for reductions in lot sizes. The OEMs have begun to demand "pull" replenishment from their supplier base. However, it is complex for this to be implemented due to the large numbers of items being handled and the large amounts of paperwork required for the quality control and traceability of so many items.

The aeronautics industry organises flows of its largest volume products with returnable packaging to guarantee cost reductions and prevent waste, and also for technical reasons, as the customised packaging provides greater physical protection to the products transported and handled between the SC members. Product protection and safety is a major concern given their high value.

To conclude, it should be highlighted that an improvement in the sector requires the integration of key processes. In this regard, for example, the development of new products has broken down the inter-organisational barriers and a high degree of integration has been achieved in the latest projects driven by high development costs, mastery of the technologies, and the need to share risks. In new product development it is especially important to design products that reduce MRO costs throughout their life cycles (MacDonnell and Clegg, 2007). 


\subsection{Organisational relationships}

This dimension presents the highest supplier and customer integration scores. This can be attributed to the need for collaboration in the aeronautics SC. Formal communications channels are set up to this end, especially between the OEMs and the first tier suppliers who hold systematic periodic meetings. However, the experts state that these meetings are used to transmit information from the OEMs but are not really discussion forums and are not used to help drive proximity between suppliers to the benefit of the SC as a whole. There is also unscheduled communication between the different SC partners because of day-to-day management or specific one-off needs due to unforeseen events.

Partners should help make the programme successful through communication and collaboration as their own success is also dependent upon it. Partners should therefore share in the common goal of satisfying the final customer, and should be aware of the risks that projects of this magnitude entail. The formula of shared risks and costs provides the necessary incentives for customer and suppliers to work together and manage complex inter-company interfaces efficiently. On the one hand, each of the companies individually seeks the best performance from the transactions for which they are jointly responsible, seeking to cut down internal costs (Sacristan Diaz et al., 2005). On the other hand, there is interdependence between the organisations and a shared interest in achieving the success of the SC as a whole. As there are individual interests and a common goal, inter-organisation processes tend to be more effective as there is an incentive realignment which means that they share in the risks, cost and reward. The main benefits for first tier suppliers in this risk, cost and reward sharing system include long-term contracts, involvement at the outset of product development and selection as the sole supply source. They can also achieve other advantages as they can purchase raw materials under an aircraft manufacturer's contracts that are extendable to its supplier base. These agreements 
envisage significant discounts for negotiated aggregated purchase volumes. The system also entails an additional benefit for the supplier if total aircraft sales exceed the negotiated number.

Although they might be seen as a benefit of the risk and cost sharing system, long-term contracts are to a large extent necessary due to the characteristics of the aeronautical product. The product's development cycle might be as long as fifteen years and the useful life of an aircraft, thirty years. This means a programme can be active for forty-five years and, together with the high development costs, this all requires relationships between SC partners to be close. Even the relationship with the final customer is marked by this long period of time as aircraft have to be maintained throughout their useful life and the manufacturer is obliged to stock spare parts and keep operations and MRO manuals up to date.

However, there is still no specific behaviour aimed at the integration of the organisations that make up the SC. They all recognise the need for integration, but see it more as an obligation rather than the result of "firm organisational conviction". The functional vision that is still present in companies and hinders the SC focus once more needs to be highlighted. In this context, lean manufacturing is being introduced into the sector and this will no doubt enable advances in improving integrated behaviour to be made. The OEMs are consolidating lean practices on the internal level and are seeking to spread the practice among their supplier bases. However, the spread of good practice is meeting with resistance given the potential fear of losing the competitive advantage gained over the competition.

This integrated behaviour should be present in the cross-functional and inter-company teams that are created to make collaboration effective. Apart from the teams established for the periodic meetings between the OEMs and first tier suppliers, teams that help to improve operations processes are also required. When technical problems relating to the products manufactured by their supplier bases arise, the OEMs and their first tier suppliers usually tackle the problems jointly with their suppliers, insofar as their knowledge of the processes involved 
allows, by providing qualified personnel and contributing to a quick and effective solution. However, inter-company and inter-functional teams only as far as specific problems and needs exist, but not on a permanent basis with the objective of improvements.

To monitor its objectives, the aeronautics industry assesses the performance of its suppliers. Basically the indicators measure on-time delivery and level of quality (or lack of quality). When the defined objectives are not met, the supplier companies must present an action plan for their indicators to reach an acceptable level. If the required indexes are not accomplished, new business developments between the two firms are normally frozen.

Performance indicators are part of systematic company communication in the sector. The OEMs communicate results compared to the goal that was set to the highest levels of the first tier suppliers on a monthly basis. However, internal communication of the results does not always reach all levels of the organisation. In other respects, although the indicators and the way that they evolve are known, the experts point out that there are no solid systematics for achieving improvements in indicators that do not reach their targets which means that, on some occasions, improvements take a long time to be achieved.

To conclude, it must be stated that the SC is not geared up for applying contingency plans if need be. Supply sources are, for the most part, unique and as there are no alternative plans established between the two parties, the SC can easily be broken if one of the links experiences some accident or unfavourable circumstance. Although the OEMs and the first tier suppliers usually have risk minimisation mechanisms in place such as supplier audits, normally there are no contingency plans, just action plans in case some problem arises.

Table 4 summarises the main strengths and weaknesses of each dimension based on the results of Table 3 (significant strength: 5 points; moderate strength: 4 points; significant weakness: 1 point; moderate weakness: 2 points) as well as possible improvement actions, which are analysed in the following section. 


\section{[INSERT TABLE 4 HERE]}

\section{Discussion and conclusions}

An integration strategy between aeronautic SC members is required if the physical and information flows are to flow smoothly and efficiently. Although variables can be found with high levels of integration, there are also others that need to be improved. The marked functional vision that exists in companies in the industry doubtlessly affects the various dimensions that were analysed. Beginning with information integration, tools, practices and initiatives can be found that support it, but there is still a clear margin for improvement. The most developed factor in this dimension is information sharing, although this information does not usually come from collaborative planning between partners. Exchange of demand and supply information between the tiers is a key SC control mechanism facilitating the flow of material downstream from the raw material producer to the final product (Bales et al., 2004). That is why tools are being created (web portals, collaborative platforms, etc.) that seek real-time, efficient and lowcost communication and the effective integration of the various SC members. Inter-company meetings are also beneficial for information integration.

However, evident weaknesses are also uncovered, as integration diminishes upstream. On one hand, more collaboration is called for in planning, since the OEMs wield great power in the SC and unilaterally set the plans for a two-year horizon. Moreover, end customer information does not flow in real time on all levels of the SC. This entails the risk of the bullwhip effect occurring. On the other hand, upstream communication tools need to be improved. The second tier suppliers and other upstream members do not usually have the financial or training capacity to implement ERPs, which means they use tools that are not integrated into the various functional areas.

Improvement actions are therefore required to achieve an increase in information integration. A strategic by-process focus would help to improve both internal and external 
integration. In other respects, second tier and upstream links should be helped to access technologies that they could address in financial and training terms (Ho et al., 2004). Applications like SAP-ECMA are in this line. Meanwhile, aeronautics clusters bring clear benefits such as cooperation between cluster members and knowledge sharing (Emiliani, 2004) and should work towards providing tools that help to improve integration information upstream. However, a common concern is that divulged information could be copied by competitors or shared with them, leading to a loss of competitive advantages. Despite these concerns, information and knowledge sharing between SC partners offers more positives than negatives; among other things, it enhances performance.

With regard to the coordination and resource sharing dimension, the highest-scoring factors are those for agreements on delivery frequency and common use of logistical equipment. The use of common logistics platforms, "milk-run" practices and returnable packaging are clear examples of the search for reductions in cost and improvements in SC efficiency. However, the sector still does not make full use of the opportunities that the "milk run" provides, such as reductions in lot size of repeatedly purchased materials or, in the final instance, the purchase of single units, with the ultimate aim of achieving a one-piece flow. In addition, the long distances and/or isolated locations between where the part is produced or stored and where it is needed present a logistics challenge, especially for the MRO activities (Farris et al., 2005). The experts also mention the need to continue advancing in the standardisation of packaging although they are aware of the difficulty that this implies given the different volumes and geometries of the pieces and the small lot sizes. As far as cooperation is concerned, they highlight the important role that company associations or clusters play as driving forces for improvements.

The worst scored factor in this dimension is work realignment with suppliers and customers. The element that has the greatest influence on maintaining work distribution with no major changes is cost. The cost incurred by changing suppliers is variable depending on the 
level in the chain where the supplier is located. Second tier suppliers are those who, in theory, can be most easily changed, but in practice this change is extremely difficult. In addition to the complex safety-tested and sealed routes, there is an exceptionally steep learning curve in this sector. When a change is made in a source of supply, the learning curve starts all over again. In other words, industrialisation begins with new methods and processes, different machines and a different labour force. These variables accentuate any mistakes and productivity, in this case the supplier's productivity, falls. This change reflects on the programme leader by impacting on the quality of the products received and causing delays in delivery, all of which, in short, generates increases in cost. Another reason for leaving the supplier base and the work load practically unchanged is the limited number of companies that operate in the sector. Little opportunity for finding alternative sources of supply means that leading industries leave their supplier base virtually untouched. According to the experts, the solution to this problem is complex, as companies that want to break into the sector have to address a high financial load due to the long manufacturing lead times and the long payment deadlines. To these are added the demands of technology, and the quality and certification demanded for becoming part of the supplier base.

The factors for long-term relationships and incentive realignment received the best scores in organisational relationship. The need to share product development costs has led OEMs to build up solid alliance relationships with their supplier bases, emphasising long-term relations. The sector is currently looking for a supplier model with integral management of work packages and the maximisation of added value. Suppliers therefore have to support each other. There is a major need for integration as their size, resources and position compared to the OEMs mean that they have to adopt collaborative strategies if they wish to meet the needs and demands of aircraft manufacturers. It is very important to share skills, ideas and tools for this reason. In this respect, the experts believe that specific forums should exist within the aeronautics 
associations or clusters for the exchange of experiences and practices. The best management solutions put forward should be circulated among the SC members.

The worst-scored factor in this dimension is establishing contingency plans. It is not normal for the sector to have well-defined plans and alternative solutions in case of some unforeseen circumstance. It should be remembered that the pieces, components, systems, etc. are exclusively designed for each model of aircraft, the number of qualified suppliers is limited and the available means of production, tools, machines, and so on, at each supplier are also exclusive. Given the special features of the industry, there are few contingency plans. For this reason the experts consider that a system needs to be established that would appropriately assess any risks with a view to corrective measures being adopted in financial and technical terms before any problems were to occur.

Previous literature states that intra-company (or internal) integration is the starting point for broader integration across the SC (Cagliano et al., 2006). In this respect, on the basis of the scores awarded by the experts it can be concluded that, broadly-speaking, the level of internal integration is greater than external integration. Nevertheless, it is evident that there is still room for improvement. With regard to external integration, it can be seen in general terms that the further upstream one goes, the lesser the degree of integration. Following the arcs of integration defined by Frohlich and Westbrook (2001), the first tier suppliers in the aeronautics sector can be stated to have a periphery-facing arc of integration, although there is greater integration with the OEMs than with second tier suppliers.

In keeping with Fisher's matrix (Fisher, 1997) the aeronautics product requires an efficient SC in which the primary goal is to minimise cost. The industry is aware of this and is starting to incorporate lean manufacturing concepts, albeit belatedly according to the experts. The current SC set up, with long lead times, intermediate inventory and other wastage during the process flow, cannot go on unchanged. Boeing has pioneered putting into practice 
improvements in efficiency through implementing lean manufacturing (Rose-Anderssen et al., 2009). At the present time, OEMs run lean programmes for internal manufacturing. The programmes are starting to bear fruit and the aircraft manufacturing companies are beginning to disseminate the techniques that they have learnt among their supplier bases. Lean initiatives will have a positive impact on improving levels of SCI (Moyano Fuentes et al., 2012).

Logistics tools also have a great potential for improvement in the sector. The use of VMI is an example of a tool that can drive SCI (Lee, 2000), as can RFID (Ramudhin et al., 2008). Boeing and Airbus already use RFID systems. This technology should be used increasingly and should undeniably contribute to improvements in visibility, communication and relationships between SC members in manufacturing and in MRO activities alike (Ramudhin et al., 2008). Both VMI and RFID implementation can efficiently contribute to neutralising the bullwhip effect by providing more accurate information more quickly.

The findings of the present paper have direct managerial implications. For the perspective of first tier suppliers, the study has brought to light deficiencies that need to be tackled if the required SCI is to be achieved. All that is left is the complex task of putting the actions in place for this to be done. Executives in other sectors may also find that the analysis in this study can act as a point-of-reference for them for improving their own SCI.

This research has been done by conducting a literature review and consulting experts. The latter entails some limitations that are considered to have been overcome by the methodological rigor followed and the characteristics of the experts chosen, all of whom have ample experience in the sector in logistics, SCM and OM. By focusing on first tier suppliers this study has been able to position itself on a key link between the powerful OEMs and the fragmented second tier suppliers, with a clear view of upstream and downstream problems. However, the next objective is to extend this study to OEMs and second tier and raw material 
Alfalla-Luque, R., Medina-Lopez, C. \& Dey, P.K. (2013), "Supply chain integration framework using literature review". Production Planning and Control, V. 24, N. 8-9, 800-817. http://dx.doi.org/10.1080/09537287.2012.666870

suppliers with the aim of presenting the situation of the aeronautics SC as a whole and the different visions that can be had depending on level in the SC that the company occupies.

\section{Acknowledgments}

The authors gratefully acknowledge the significant contributions made by the anonymous reviewers to improving this paper. The authors also would like to express their gratitude for financial support from the Spanish Ministry of Education JC2010-0106 research grant, the University of Seville Research Plan and the Andalusian Regional Government.

\section{References}

AeroStrategy Management Consulting, 2007. Winds of change. AeroStrategy Comentary, March, 1-8.

Alfalla-Luque, R. and Medina-Lopez, C., 2009. Supply Chain Management: Unheard of in the 1970s, core to today's company. Business History, 51(2), 201-220.

Alfalla-Luque, R. and Medina-Lopez, C., 2010. Gestionar más allá de los límites de la empresa individual: una oportunidad para obtener ventajas competitivas. Economía y Administración, 1(2): 114-137.

Anderson, M., 1995. The role of collaborative integration in industrial organization: observations from the Canadian aerospace industry. Economic Geography, 71(1), 55-78.

Arana-Solares, I., Machuca, J.A.D. and Alfalla-Luque, R., 2011. Proposed Framework for Research in the Triple A (Agility, Adaptability, Alignment) in Supply Chains. In: B. Flynn, M. Morita and J.A.D. Machuca, eds. Managing Global Supply Chain Relationships: Operations, Strategies and Practices. USA: IGI Global, 306-321.

Bagchi, P.K., Ha, B.C. and Skjoett-Larsen, T., 2005b. Supply chain integration in Europe: a status report. AIB Conference, Canada.

Bagchi, P.K., Ha, B.C., Skjoett-Larsen, T. and Soerensen, L.B., 2005a. Supply chain integration: a European survey. The International Journal of Logistic Management, 16(2), 275-294.

Bales, R.R., Maull, R.S. and Radnor, Z., 2004. The development of supply chain management within the aerospace manufacturing sector. Supply Chain Management, 9(3), 250-255.

Barbour, R.S. and Kitzinger, J., 1999. Developing Focus Group Research: Introduction: the challenge and promise of focus groups. In: R.S. Barbour and J. Kitzinger, eds. Developing Focus Group Research: Politics, Theory and Practice. London: Sage Publications.

Binder, M. and Edwards, J. S., 2010. Using grounded theory method for theory building in operations management research. A study on inter-firm relationship governance. International Journal of Operations \& Production Management, 30(3), 232-259.

Bozdogan, K., Deyst, J., Hoult, D. and Lucas, M., 1998. Architectural innovation in product development through early supplier integration. $R \& D$ Management, 28(3), 163-173.

Briscoe, G. and Dainty, A., 2005. Construction supply chain integration: An elusive goal? Supply Chain Management, 10(4), 319-326.

Brookes, N.J., Morton S.C., Grossman, S., Joesbury, P. and Varnes, D., 2007. Analyzing Social Capital to Improve Product Development Team Performance: Action-Research Investigations 
in the Aerospace Industry with TRW and GKN. IEEE Transactions on Engineering Management, 54(4), 814-830.

Cagliano, R., Caniato, F. and Spina, G., 2006. The linkage between supply chain integration and manufacturing improvement programmes. International Journal of Operations and Production Management, 26(3), 282-299.

Cagliano, R., Caniato, F., Corso, M., and Spina, G. 2005. Collaborative improvement in the extended manufacturing enterprise: Lessons from an action research process. Production Planning \& Control, 16(4), 345-355.

Cigolini, R. and Rossi, T., 2008. Evaluating supply chain integration: A case study using fuzzy logic. Production Planning \& Control, 19(3), 242-255.

Cousins, P.D. and Menguc, B., 2006. The implications of socialization and integration in supply chain management. Journal of Operations Management, 24(5), 604-620.

Crute, V., Ward, Y., Brown, S. and Graves, A., 2003. Implementing Lean in aerospace Challenging the assumptions and understanding the challenges. Technovation, 23(12), 917928.

Dey, P.K., Hariharan, S. and Clegg, B.T., 2006. Measuring the operational performance of intensive care units using the analytic hierarchy process approach. International Journal of Operations \& Production Management, 26(8), 849-865.

Ecorys, 2009. Competitiveness of the EU Aerospace Industry with focus on Aeronautics Industry. Final Report [on-line]. European Commision. Avalaible from: http://ec.europa.eu/ enterprise/sectors/aerospace/market-data/index_en.htm [Accesed 17 January 2011].

Eisenhardt, K.M., 1989. Building theories from case study research. Academy of Management Review, 14(4), 532-550.

Emiliani, M.L., 2004. Sourcing in the global aerospace supply chain using online reverse auctions. Industrial Marketing Management, 33(1), 65-72.

Esposito, E. and Passaro, R., 2009. The evolution of supply chain relationships: An interpretative framework based on the Italian inter-industry experience. Journal of Purchasing and Supply Management, 15(2), 114-126.

Farris II, M.T., Wittmann C.M. and Hasty, R., 2005. Aftermarket support and the supply chain: Examples and implications from the aerospace industry. International Journal of Physical Distribution \& Logistics Management, 35(1), 6-19.

Fisher, M.L., 1997. What is the right supply chain for your product? Harvard Business Review, March-April, 105-116.

Flynn, B.B., Huo, B. and Zhao, X., 2010. The impact of supply chain integration on performance: A contingency and configuration approach, Journal of Operations Management, 28(1), 58-71

Frear, C.R. and Metcalf, L.E., 1995. Strategic alliances and technology networks: A study of a cast-products supplier in the aircraft industry. Industrial Marketing Management, 24(5), 379390.

Frohlich, M.T. and Westbrook, R., 2001. Arcs of integration: An international study of supply chain strategies. Journal of Operations Management, 19(2), 185-200.

Gary, G. and Pervaiz A., 2000. Buyer-supplier management in the aerospace value chain. Integrated Manufacturing Systems, 11(7), 462-468.

Gimenez, C. and Ventura, E., 2005. Logistics-production, logistics-marketing and external integration, their impact on performance. International Journal of Operations \& Production Management, 25(1), 20-38.

Grant, S.B., 2003. Early supplier involvement in new product development within the UK aerospace industry. International. Journal of Electronic Business, 1(4), 329-246.

Gulledge, T., 2002. B2B eMarketplaces and small- and medium-sized enterprises. Computers in Industry, 49(1), 47-58. 
Hernández, J.E., Poler, R., Mula, J. and Peidro D., 2008. A collaborative knowledge management framework for supply chains: A UML-based model approach. Journal of Industrial Engineering and Management, 1(2), 77-103.

Ho, P., Trappey, A.J.C. and Trappey, C.V., 2004. Data interchange services: Use of XML hub approach for the aerospace supply chain. International Journal of Technology Management, 28(2), 227-242.

Kannan, V.R. and Tan, K.C., 2005. Just in time, total quality management, and supply chain management: understanding their linkages and impact on business performance. Omega, 33 (2), 153-162.

Ketchen, D.J. and Hult, G.T.M., 2007. Bridging organization theory and supply chain management: The case of best value supply chains. Journal of Operations Management, 25, 573-580.

Kim, S.W., 2009. An investigation on the direct and indirect effect of supply chain integration on firm performance. International Journal of Production Economics, 119(2), 328-346.

Koufteros, X.A., Cheng, T.C.E. and Lai, K.H., 2007. "Black-box"' and "gray-box"' supplier integration in product development: Antecedents, consequences and the moderating role of firm size. Journal of Operations Management, 25, 847-870.

Laframboise, K. and Reyes, F., 2007. The digitization of an aerospace supply network. International Journal of Enterprise Information Systems, 3(2), 68-89.

Lee, H.L., 2000. Creating Value through Supply Chain Integration. Supply Chain Management Review, 4(4), 30-36.

Lummus, R., Melnyk, S.A., Vokurka, R.J., Burns, L., and Sandor, J, 2007. Getting ready for tomorrow's supply chain. Supply Chain Management Review, 11(6), 48-56.

MacDonnell, M. and Clegg, B., 2007. Designing a support system for aerospace maintenance supply chains. Journal of Manufacturing Technology Management, 18(2), 139-152.

Mentzer, J.T., DeWitt, W., Keebler, J.S. and Min, S., 2001. Defining supply chain management. Journal of Business Logistics, 22(2), 1-25.

Mikkola, J.H. and Skjøtt-Larsen, T., 2004. Supply-chain integration: Implications for mass customization, modularization and postponement strategies. Production Planning \& Control, 15(4), 352-361.

Morton, S.C., Dainty, R.J., Burns, N.D., Brookes, N.J. and Backhouse, C.J., 2006. Managing relationships to improve performance: a case study in the global aerospace industry. International Journal of Production Research, 44 (16), 3227-3241.

Moyano Fuentes, J., 2010. The Influence of the Supply Chain Integration on the Level of Implementation of e-Business Capabilities. Universia Business Review, 28, 30-45.

Moyano Fuentes, J., Martínez Jurado, P.J., Maqueira Marín, J.M. and Bruque Cámara, S., 2012. El papel de las TIC en la búsqueda de la eficiencia: Un análisis desde Lean Production y la integración electrónica de la cadena de suministro. Cuadernos de Economía y Dirección de la Empresa (in press).

Narasimhan, R. and Kim, S.W., 2002. Effect of supply chain integration on the relationship between diversification and performance: Evidence from Japanese and Korean firms. Journal of Operations Management, 20(3), 303-323.

Oehmen, J., De Nardo, M., Schönsleben, P. and Boutellier, R., 2010. Supplier code of conductstate-of-the-art and customisation in the electronics industry. Production Planning \& Control, 21(7), 664-679.

O'Leary-Kelly, S.W. and Vokurka, R.J., 1998. The Empirical Assessment of Construct Validity. Journal of Operations Management, 16(4), 387-405.

O'Sullivan, A., 2003. Dispersed collaboration in a multi-firm, multi-team product-development project. Journal of Engineering and Technology Management - JET-M, 20(1-2 SPEC.), 93116. 
Paliwoda, S.J. and Bonaccorsi, A.J., 1994. Trends in procurement strategies within the European aircraft industry. Industrial Marketing Management, 23(3), 235-244.

Parry, G. C., and Turner, C. E. 2006. Application of lean visual process management tools. Production Planning \& Control, 17(1), 77-86.

Quesada, G., Rachamadugu, R., Gonzalez, M. and Martinez, J.L., 2008. Linking order winning and external supply chain integration strategies. Supply Chain Management, 13(4), 296-303.

Ramudhin, A., Paquet, M., Artiba, A., Dupré, P., Varvaro, D. and Thomson, V., 2008. A generic framework to support the selection of an RFID-based control system with application to the MRO activities of an aircraft engine manufacturer. Production Planning \& Control, 19(2), 183-196.

Reed, F.M. and Walsh, K., 2002. Enhancing technological capability through supplier development: A study of the U.K. aerospace industry. IEEE Transactions on Engineering Management, 49(3), 231-242.

Rose-Anderssen, C., Baldwin, J., Ridgway, K., Allen, P., Varga, L. and Strathern, M., 2009. A cladistic classification of commercial aerospace supply chain evolution. Journal of Manufacturing Technology Management, 20(2), 235-257.

Rose-Anderssen, C., Baldwin, J.S., Ridgway, K., Allen, P.M. and Varga, L., 2008. Aerospace Supply Chains as Evolutionary Networks of Activities: Innovation via Risk-Sharing Partnerships. Creativity and Innovation Management, 17(4), 304-318.

Rosenzweig, E.D., Roth, A.V. and Dean, J.W., 2003. The influence of an integration strategy on competitive capabilities and business performance: an exploratory study of consumer products manufacturers. Journal of Operations Management, 21, 437-56.

Rota, K., Thierry, C., and Bel, G. 2002. Supply chain management: A supplier perspective. Production Planning \& Control, 13(4), 370-380.

Russell, D.M. and Hoag, A.M., 2004. People and information technology in the supply chain. International Journal of Physical Distribution and Logistics Management, 34(2), 102-122.

Sacristán Díaz, M.; Álvarez Gil, M.J. and Machuca, J.A.D., 2005. Performance Measurement Systems, Competitive Priorities, and Advanced Manufacturing Technology: Some evidence from the Aeronautical Sector. International Journal of Operations \& Production Management, 25(8), 781-799.

Sahin, F. and Robinson, E.P., 2005. Information sharing and coordination in make-to-order supply chains, Journal of Operations Management, 23(6), 579-598.

Sanders, N.R. and Premus, R., 2005. Modeling the relationship between firm IT capability, collaboration, and performance. Journal of Business Logistics, 26(1), 1-23.

Sezen, B., 2008. Relative effects of design, integration and information sharing on supply chain performance. Supply Chain Management: An International Journal, 13(3), 233-240.

Smith, D.J. and Tranfield, D., 2005. Talented suppliers? Strategic change and innovation in the UK aerospace industry. $R \& D$ Management, 35(1), 37-49.

Stank, T.P., Keller, S.B. and Daugherty, P.J., 2001. Supply chain collaboration and logistical service performance. Journal of Business Logistics, 22(1), 29-48.

Stewart, D.W. and Shamdasani, P.N., 1990. Focus Groups. Theory and Practice. 1st ed. Applied Social Research Methods Series. Vol. 20. California, USA: Sage Publications.

Swink, M., Narasimhan, R. and Wang, C., 2007. Managing beyond the factory walls: Effects of four types of strategic integration on manufacturing plant performance. Journal of Operations Management, 25(1), 148-164.

Tan, K.C., Lyman, S.B. and Wisner, J.D., 2002. Supply chain management: a strategic perspective. International Journal of Operations \& Production Management, 22(5), 614631.

Tate, W.L., Ellram, L.M., Bals, L., Hartmann, E. and Van der Valk, W., 2010. An Agency Theory perspective on the purchase of marketing services. Industrial Marketing 
Management, 39, 806-819.

Vachon, S. and Klassen, R.D., 2007. Supply chain management and environmental technologies: The role of integration. International Journal of Production Research, 45(2), 401-423.

Vickery, S.K., Jayaram, J., Droge, C. and Calantone, R., 2003. The effects of an integrative supply chain strategy on customer service and financial performance: An analysis of direct versus indirect relationships. Journal of Operations Management, 21(5), 523-539.

Wong, C.Y. and Boon-Itt, S., 2008. The influence of institutional norms and environmental uncertainty on supply chain integration in the Thai automotive industry. International Journal of Production Economics, 115(2), 400-410

Zhang, X., Huang, G.Q., Humphreys, P.K. and Botta-Genoulaz, V., 2010. Simultaneous configuration of platform products and manufacturing supply chains: comparative investigation into impacts of different supply chain coordination schemes. Production Planning \& Control, 21(6), 609-627.

Zsidisin, G.A. and Smith, M.E., 2005. Managing supply risk with early supplier involvement: A case study and research propositions. Journal of Supply Chain Management, 41(4), 44-57.

Zuckerman, A., 2007. Aerospace-Defense Sector First to Employ Collaborative Supply Chain Platform. World Trade, 20(1), 52-57. 
Alfalla-Luque, R., Medina-Lopez, C. \& Dey, P.K. (2013), "Supply chain integration framework using literature review". Production Planning and Control, V. 24, N. 8-9, 800-817. http://dx.doi.org/10.1080/09537287.2012.666870

\section{Table(s) with caption(s)}

Table 1. Correspondences between Lee's (2000) and Bagchi et al.'s (2005b) dimensions.

\begin{tabular}{|l|l|}
\hline Lee (2000) & Bagchi et al. (2005b) \\
\hline - Information integration & - Information sharing and communication across the supply chain \\
\hline - Coordination and resource sharing & - Collaboration and shared decision-making with network partners \\
\hline - Organisational relationship linkage & $\begin{array}{l}\text { - Collaboration leading to risk, cost, and gain sharing (operational and } \\
\text { strategic collaboration) }\end{array}$ \\
& $\begin{array}{l}\text { - Sharing of skills, ideas, and institutional culture } \\
\text { - Organisation }\end{array}$ \\
\hline
\end{tabular}

Table 2. Articles that study aspects related to each SCI dimension in the aeronautics sector

\begin{tabular}{|l|l|}
\hline Dimension & Article \\
\hline $\begin{array}{l}\text { Information } \\
\text { integration (II) }\end{array}$ & $\begin{array}{l}\text { Bales et al. (2004); Emiliani (2004); Esposito and Passaro (2009); Farris et al. (2005); Gulledge } \\
\text { (2002); Ho et al. (2004); Laframboise and Reyes (2007); MacDonnell and Clegg (2007); } \\
\text { O'Sullivan (2003); Paliwoda and Bonaccorsi (1994); Pankaj and Larry (2004); Reed and Walsh } \\
\text { (2002); Rota et al. (2002); Russell and Hoag (2004); Zuckerman (2007) }\end{array}$ \\
\hline $\begin{array}{l}\text { Coordination } \\
\text { and resource } \\
\text { sharing (CRS) }\end{array}$ & $\begin{array}{l}\text { Anderson (1995); Bales et al. (2004); Bozdogan et al. (1998); Esposito and Passaro (2009); Gary } \\
\text { and Pervaiz (2000); Grant (2003); Paliwoda and Bonaccorsi (1994); Farris et al. (2005); Pankaj } \\
\text { and Larry (2004); Smith and Tranfield (2005) }\end{array}$ \\
\hline $\begin{array}{l}\text { Organisational } \\
\text { relationship } \\
\text { linkage (ORL) }\end{array}$ & $\begin{array}{l}\text { Anderson (1995); Bales et al. (2004); Brookes et al. (2007); Cagliano et al. (2005); Esposito and } \\
\text { Passaro (2009); Farris et al. (2005); Frear and Metcalf (1995); Gary and Pervaiz (2000); Morton et } \\
\text { al. (2006); Paliwoda and Bonaccorsi (1994); Pankaj and Larry (2004); Rose-Anderssen et al. } \\
\text { (2008); Smith and Tranfield (2005); Zsidisin and Smith (2005) }\end{array}$ \\
\hline
\end{tabular}

Table 3. Ratings for SCI in the aeronautics sector

\begin{tabular}{|c|c|c|c|c|}
\hline \multirow[b]{2}{*}{ Dimensions } & \multirow[b]{2}{*}{ Variables } & \multicolumn{3}{|c|}{ Level of integration (Tier 1) with } \\
\hline & & $\begin{array}{l}\text { Suppliers } \\
\text { (Tier2) }\end{array}$ & $\begin{array}{l}\text { Internal } \\
\text { (Tier1) }\end{array}$ & $\begin{array}{c}\text { Customers } \\
\text { (OEMs) }\end{array}$ \\
\hline \multirow{5}{*}{$\begin{array}{l}\text { Information } \\
\text { integration } \\
\text { (II) }\end{array}$} & Information sharing & 3 & 4 & 5 \\
\hline & Information technology integration & 3 & 3 & 4 \\
\hline & Collaborative planning & 1 & 3 & 1 \\
\hline & Joint demand forecasts. Real-time and end customer information & 3 & 3 & 2 \\
\hline & Joint replenishment forecasts & 2 & 4 & 3 \\
\hline \multirow{8}{*}{$\begin{array}{l}\text { Coordination } \\
\text { and resource } \\
\text { sharing } \\
\text { (CRS) }\end{array}$} & Shared decision-making & 1 & 4 & 2 \\
\hline & Cooperation & 3 & 3 & 4 \\
\hline & Work realignment & 1 & 4 & 1 \\
\hline & Reorganisation of outsourcing. Common use of 3PL & 2 & - & 1 \\
\hline & Packaging customisation/standardisation & 3 & - & 4 \\
\hline & Agreements on delivery frequency & 3 & - & 5 \\
\hline & Common use of logistical equipment/containers & 4 & - & 5 \\
\hline & Process integration & 3 & 4 & 3 \\
\hline \multirow{9}{*}{$\begin{array}{l}\text { Organisational } \\
\text { relationship } \\
\text { linkage (ORL) }\end{array}$} & Design and maintaining of communication channels & 3 & 4 & 4 \\
\hline & Laying down performance measures & 4 & 3 & 5 \\
\hline & $\begin{array}{l}\text { Incentive realignment: collaboration leading to risk, cost, and } \\
\text { reward sharing (operational and strategic collaboration) }\end{array}$ & 4 & - & 4 \\
\hline & Integrated behaviour & 3 & 3 & 2 \\
\hline & Joint establishment of objectives for all parties in the chain & 3 & 3 & 4 \\
\hline & Sharing of skills, ideas, and institutional culture & 3 & 3 & 2 \\
\hline & Drawing up of contingency plans for quick problem solving & 2 & 2 & 1 \\
\hline & Forging and maintaining long-term relationships & 4 & - & 4 \\
\hline & Creating Teamwork along SC and cross-functional teams & 3 & 4 & 3 \\
\hline
\end{tabular}


Alfalla-Luque, R., Medina-Lopez, C. \& Dey, P.K. (2013), "Supply chain integration framework using literature review". Production Planning and Control, V. 24, N. 8-9, 800-817. http://dx.doi.org/10.1080/09537287.2012.666870

Table 4. Main strengths and weaknesses in each SCI dimension

\begin{tabular}{|c|c|c|c|}
\hline & Strengths & Weaknesses & Possible improvement actions \\
\hline$\exists$ & $\begin{array}{l}\text { (++) Information sharing with } \\
\text { OEMs } \\
\text { (+) Information technology } \\
\text { integration with OEMs } \\
\text { (+) Internal information sharing } \\
\text { (+) Internal joint replenishment } \\
\text { forecasts }\end{array}$ & $\begin{array}{l}\text { (--) Collaborative } \\
\text { planning with } \\
\text { suppliers } \\
\text { (--) Collaborative } \\
\text { planning with } \\
\text { OEMs } \\
\text { (-) Joint demand } \\
\text { forecasts with } \\
\text { OEMs } \\
\text { (-) Joint replenishment } \\
\text { forecasts with } \\
\text { suppliers }\end{array}$ & $\begin{array}{l}\text { Use of collaborative work platforms along the SC (especially } \\
\text { increased connectivity upstream) } \\
\text { Establish systematic and programmed meetings between Tier1 } \\
\text { and suppliers upstream } \\
\text { Increased direct information between OEMs and Tier2 and } \\
\text { upstream } \\
\text { Increased end customer information upstream } \\
\text { Improved upstream communication tools and collaborative } \\
\text { planning } \\
\text { Aeronautics clusters directed at improving integration } \\
\text { information upstream } \\
\text { Adoption of a strategic by-process focus along the SC } \\
\text { Access of Tier2 and upstream to ERP systems and IT tools } \\
\text { Improve ERP systems to reflect MRO activities }\end{array}$ \\
\hline & $\begin{array}{l}++) \text { Agreements on delivery } \\
\text { frequency with OEMs } \\
\text { (++) Common use of logistical } \\
\text { equipment with OEMs } \\
\text { (+) Internal shared decision- } \\
\text { making } \\
\text { (+) Internal work realignment } \\
\text { (+) Internal process integration } \\
\text { (+) Cooperation with OEMs } \\
\text { (+) Packaging customisation/ } \\
\text { standardisation with OEMs } \\
\text { (+) Common use of logistical } \\
\text { equipment with suppliers }\end{array}$ & $\begin{array}{l}\text { (--) Shared decision- } \\
\text { making with } \\
\text { suppliers } \\
\text { (--) Work realignment } \\
\text { with suppliers and } \\
\text { OEMs } \\
\text { (--) Reorganisation of } \\
\text { outsourcing with } \\
\text { OEMs } \\
\text { (-) Reorganisation of } \\
\text { outsourcing with } \\
\text { suppliers } \\
\text { (-) Shared decision- } \\
\text { making with OEMs }\end{array}$ & $\begin{array}{l}\text { Continue with change from traditional model to one of first tier } \\
\text { suppliers with solid resources for managing their raw } \\
\text { materials and their production processes. } \\
\text { Improved management, technical and financial capacity of } \\
\text { upstream suppliers } \\
\text { Increased limited possible partners upstream } \\
\text { Continue advancing in packaging customisation and } \\
\text { standardisation to achieve more agile and flexible logistics } \\
\text { Increase the use of milk run systems } \\
\text { Improve logistics in MRO activities } \\
\text { Reinforced use of returnable packaging seeking cost reduction } \\
\text { and waste prevention } \\
\text { Reinforced role of aeronautics cluster to tackle SC partners' } \\
\text { technical and management difficulties } \\
\text { Develop use of VMI and RFID in the sector } \\
\text { Increased intensity of lean implementation }\end{array}$ \\
\hline$\vec{v}$ & $\begin{array}{l}(++) \text { Laying down performance } \\
\text { measures with OEMs } \\
(+) \text { Creating internal cross- } \\
\text { functional teamwork } \\
\text { (+)Designing and maintaining } \\
\text { communication channels } \\
\text { internally and with OEMs } \\
\text { (+) Joint establishment of } \\
\text { objectives for all parties in the } \\
\text { chain and OEMs } \\
(+) \text { Incentive realignment with } \\
\text { suppliers and OEMs } \\
(+) \text { Forging and maintaining } \\
\text { long-term relationships with } \\
\text { suppliers and OEMs } \\
\text { (+) Laying down performance } \\
\text { measures with suppliers }\end{array}$ & $\begin{array}{l}\text { (--) Drawing up of } \\
\text { contingency plans } \\
\text { for quick problem } \\
\text { solving with OEMs } \\
\text { (-) Drawing up of } \\
\text { contingency plans } \\
\text { for quick problem } \\
\text { solving internally } \\
\text { and with suppliers } \\
\text { (-) Integrated } \\
\text { behaviour with } \\
\text { OEMs } \\
\text { (-) Sharing of skills, } \\
\text { ideas, and } \\
\text { institutional culture } \\
\text { with OEMs }\end{array}$ & $\begin{array}{l}\text { Develop mechanisms for prevention, contingency plans and } \\
\text { alternative solutions } \\
\text { Assess any risk in order to take financial and technical } \\
\text { corrective measures } \\
\text { Design a monitoring and continuous control process for short- } \\
\text { term solutions } \\
\text { Adopt a process approach along the SC } \\
\text { Develop suppliers competent to execute integral management } \\
\text { of work packages and maximise added value } \\
\text { Adopt collaborative strategies } \\
\text { Improve integrated behaviour of the SC partners, for example, } \\
\text { through the use of lean practices } \\
\text { Establish specific forums within the aeronautics clusters for the } \\
\text { exchange of experiences and best practices. } \\
\text { Enhance the creation of cross-functional and inter-company } \\
\text { teams on a permanent basis }\end{array}$ \\
\hline
\end{tabular}

(++) Significant strength (+) Moderate strength (--) Significant weakness (-) Moderate weakness 